\title{
KEADILAN PROSEDURAL PARTISIPATIF DAN DUKUNGAN SERIKAT PEKERJA TERHADAP KEPUASAN KERJA
}

\author{
Asep Qustolani \\ Dosen Universitas Majalengka \\ E Mail : Asepquinn@Yahoo.Com
}

\begin{abstract}
ABSTRAK
Penelitian ini bertujuan untuk mengetahui bagaimana pengaruh Keadilan Prosedural Partisipatif dan Dukungan Serikat Pekerja terhadap Kepuasan Kerja karyawan pada Super Market UD. Putra TS Majalengka. Hipotesis yang di ajukan dalam penelitian ini adalah bahwa Keadilan Prosedural Partisipatif dan Dukungan Serikat Pekerja berpengaruh signifikan terhadap Kepuasan Kerja, dimana populasi di dalam penelitian ini adalah karyawan Super Market UD. Putra TS Majalengka yang di ambil sebagai responden yakni berjumlah 100 orang. Metode penelitian yang digunakan menggunakan metode survey dengan pendekatan deskriptif verifikatif. Alat analisis yang digunakan dalam penelitian ini adalah asumsi klasik, analisis regresi berganda, koefisien determinasi, dan uji hipotesis untuk uji parsial menggunakan uji t dan uji simultan menggunakan uji $\mathrm{F}$, sehingga hasil penelitian menunjukan bahwa keadilan prosedural partisipatif dan dukungan serikat pekerja berpengaruh signifikan terhadap kepuasan kerja karyawan artinya semakin baik keadilan prosedural partisipatif dalam diri karyawan dan semakin baik dukungan serikat pekerja yang diberikan kepada karyawan maka akan semakin tinggi pula tingkat kepuasan kerja karyawan.
\end{abstract}

Kata kunci : Keadilan Prosedural Partisipatif.

\section{ABSTRACT}

This study aims to determine how the influence of Justice Procedural Participatory and Trade Union Support to Job Satisfaction of employees at UD. Putra TS Majalengka. The hypothesis proposed in this research is that Participatory Procedural Justice and Trade Union Support have a significant effect on Job Satisfaction, so that population in this research is UD Putra TS Super Market Majalengka taken as respondents that amounted to 100 people. The research method used survey method with descriptive approach verifikatif. The analysis tools used in this study are classical assumption, multiple regression analysis, coefficient of determination, and hypothesis test for partial test using t test and simultaneous test using $F$ test. The results showed that participative procedural justice and union support had a significant effect on employee job satisfaction which means better procedural paticifative justice in the employees and the better the union support to employees will increase employee job satisfaction.

Keywords: Participative Procedural Justice.

\section{PENDAHULUAN}

Setiap perusahaan terus berusaha
meningkatkan dan mengembangkan perusahaan
dengan berbagai cara untuk mencapai tujuan.
Tujuan tersebut diraih dengan memanfaatkan
sumber daya yang ada salah satunya sumber daya
manusia. Sumber daya manusia memiliki peran
yang sangat penting bagi perusahaan. Jika tidak ada
sumber daya manusia yang baik maka perusahaan
tersebut tidak dapat mencapai tujuan perusahaan.

Keberhasilan suatu organisasi dapat dilihat oleh salah satu faktornya yaitu kepuasan kerja karyawan. Pada umumnya kepuasan kerja mencerminkan perasaan pekerja pada pekerjaannya. Hal ini ditunjukan dalam sikap pekerja di lingkungan kerjanya, seperti bekerja dengan giat, tekun, penuh semangat, tidak mengeluh dan sikap positif lainnya. Jika dalam sebuah organisasi tercipta kepuasan kerja maka pekerja akan memberikan kualitas kerja yang lebih baik terhadap pekerjaannya. Menurut Gibson (1996 : 150) Kepuasan kerja adalah suatu sikap yang dipunyai individu mengenai pekerjaannya. Hal ini dihasilkan 
dari persepsi mereka terhadap pekerjaannya, didasarkan pada faktor lingkungan kerja seperti gaji, kebijakan dan prosedur, afiliasi dan kelompok kerja, kondisi kerja dan tunjangan.

Setiap individu memiliki kepuasan yang berbeda-beda sesuai dengan sistem nilai yang berlaku pada dirinya. Semakin tinggi penilaian terhadap kegiatan dirasakan sesuai dengan keinginan individu, maka akan semakin tinggi pula kepuasannya terhadap kegiatan tersebut. Dengan demikian, kepuasan merupakan evaluasi yang menggambarkan seseorang atas perasaan sikapnya senang atau tidak senang, puas atau tidak puas dalam bekerja (Veithzal Rivai, 2011 : 856).

Keberhasilan dan kepuasan kerja seseorang ditentukan oleh beberapa faktor salah satunya yaitu keadilan prosedural partisipatif, sesuai hasil penelitian dalam disertasi Asep Qustolani (2015).

Kepuasan kerja karyawan saat ini menjadi prioritas utama bagi suatu perusahaan dimana kepuasan kerja karyawan akan memberikan dampak langsung terhadap perusahaan tersebut yang dipengaruhi oleh keadilan prosedural partisipatif dan dukungan serikat pekerja.

Karyawan merasakan puas terhadap perusahaan memang memiliki banyak faktor, salah satunya adalah tentang keadilan organisasi khususnya keadilan prosedural partisipatif maka karyawan akan merasa dihargai dan diperlakukan secara adil sebagaimana mestinya.

Selain itu, faktor yang dapat meningkatkan kepuasan kerja adalah dukungan serikat pekerja, karena serikat pekerja adalah satu satunya wadah yang bisa mewakili suara dari karyawan, sehingga apabila dukungan serikat pekerja sesuai dengan harapan karyawan maka kepuasan karyawanpun akan meningkat. Menurut Budiarti (2011) Dukungan serikat pekerja adalah keberadaan organisasi yang dapat dirasakan manfaatnya oleh anggotanya karena organisasi itu benar-benar dapat berfungsi sebagaimana mestinya.

Serikat pekerja sendiri dapat diartikan sebagai sebuah organisasi demokratis yang berkesinambungan, mandiri, dan permanen dibentuk secara sukarela dari, oleh dan untuk serta dibiayai pekerja. Pemberian dukungan yang baik diberikan oleh serikat pekerja akan membuat karyawan merasa terlindungi hak dan kewajibannya. Pada akhirnya ketika karyawan telah merasa terlindungi mereka akan merasa nyaman berada di tempat kerjanya sehingga kepuasan kerja pun akan meningkat dengan baik.

UD. Putra TS merupakan salah satu super market yang berada di daerah Majalengka yang bergerak di bidang fashion dan menyediakan berbagai perlengkapan sekolah, mainan anak-anak, dan lainnya. Jumlah karyawannya saat ini mencapai 320 orang. Meskipun memiliki karyawan yang tidak sedikit, pemilik dari usaha ini tetap memprioritaskan kepuasan kerja dengan cara memberikan penghargaan selama satu tahun sekali berupa finansial maupun non finansial kepada dua orang karyawan teladan yang memiliki dedikasi tinggi terhadap perusahaan.

\section{TINJAUAN PUSTAKA}

Karyawan adalah aset yang mempunyai andil terbesar terhadap kemajuan perusahaan. Penanganan yang tidak tepat akan menghambat pencapaian tujuan perusahaan. Jadi karyawan merupakan faktor strategis dalam semua kegiatan perusahaan.

\section{Keadilan Prosedural Partisipatif}

Keadilan prosedural partisipatif adalah,"persepsi terhadap keadilan yang berkaitan dengan prosedur, mengacu pada kewajaran proses keputusan yang dibuat disertai dengan peran serta dari karyawan. Faktor ini berpotensi unuk meningkatkan kepuasan kerja karyawan yang bisa berdampak pada kinerja". (Asep Qustolani, 2015). Lebih lanjut dikemukakan bahwa indikatornya adalah sebagai berikut: Pertama: Konsisten, Prosedur yang adil harus konsisten baik dari orang satu kepada orang lainnya maupun dari waktu ke waktu. Setiap orang memiliki hak dan diperlakukan sama dalam prosedur yang sama. Kedua: Perbaikan, Upaya untuk memperbaiki kesalahan merupakan salah satu tujuan penting perlu ditegakan keadilan. Oleh karena itu, prosedur yang adil juga mengandung aturan yang bertujuan mempertimbangkan prosedur-prosedur yang ada untuk memperbaiki kesalahan yanga ada atau pun kesalahan yang mungkin akan muncul. Ketiga: Representatif / Keterwakilan, Prosedur dikatakan adil jika sejak awal ada upaya untuk melibatkan semua pihak yang bersangkutan. Meskipun keterlibatan yang dimaksudkan dapat disesuaikan dengan sub-sub kelompok yang ada, secara prinsip harus ada pernyertaan dari berbagai pihak sehingga akses untuk melakukan kontrol juga terbuka. Keempat: Gagasan atau ide, Setiap individu memiliki hak untuk mengemukakan gagasan atau ide baik secara lisan maupun tulisan, adanya kebebasan mengemukakan gagasan atau ide hendaknya harus dilakukan dengan penuh tanggung jawab serta memperhatikan peraturan yang ada. Kelima: Keaktifan dalam rapat, Seseorang yang mampu mengikuti jalannya suatu pertemuan antar individu atau pimpinan dengan staffnya dan memiliki kesempatan yang sama untuk mengemukakan pendapat.Setiap individu dikatakan aktif apabila orang tersebut mengikuti, memahami 
dan berani mengemukakan pendapatnya. Keenam: Koordinasi, Perihal mengatur suatu organisasi atau kegiatan sehingga peraturan dan tindakan yang akan dilaksanakan tidak saling bertentangan atau simpang siur.

\section{Dukungan Serikat Pekerja}

Serikat pekerja merupakan sebuah organisasi yang mewadahi kebutuhan pekerja setiap waktu dan berfungsi sebagai alat untuk memperjuangkan, melindungi, membela kepentingan dan kesejahteraan pekerja serta keluarganya.

Kehadiran serikat pekerja secara signifikan mengubah beberapa aktivitas sumber daya manusia. Proses perekrutan, prosedur seleksi, tingkat-tingkat upah, kenaikan gaji, paket tunjangan, sistem keluhan, dan prosedur disiplin dapat berubah secara drastis disebabkan oleh persyaratan perjanjian perburuhan (labor agreement). Kebanyakan pekerja menginginkan upah yang tinggi dan kondisi kerja yang baik, artinya pekerja dapat melaksanakan pekerjaannya terlindung dari kemungkinan kecelakaan maupun kondisi kerja yang baik, antara lain hubungan kerja yang harmonis antarpekerja maupun antar pekerja dengan perusahaan. Dukungan serikat pekerja memiliki peran yang sangat penting dalam melindungi hak dan kewajiban pekerja (Hamong Santoso dan Indi Djastuti, 2011).

Serikat pekerja memang harus berpihak kepada pekerja bukan pengusaha, namun keberpihakannya harus mempunyai sifat yang obyek, terbuka serta bertanggungjawab. Karena serikat pekerja sebagai wadah untuk menampung aspirasi pekerjaannya, maka dengan demikian serikat pekerja harus mengoptimalkan kinerjanya dengan salah satu caranya yaitu meningkatkan partisipasi anggotanya, supaya apa yang menjadi harapan-harapan anggotanya dapat tercapai.

Fungsi atau layanan utama paling dasar yang disediakan oleh serikat pekerja kepada anggota-anggotanya adalah negosiasi dan keterwakilan. Terdapat pula beberapa manfaatmanfaat lain yang dapat diperoleh dengan menjadi anggota serikat pekerja yaitu menyampaikan aspirasi pekerja.

Berikut indikator dari dukungan serikat pekerja menurut Budiarti (2011) :

Sebagai sarana bernegosiasi, dapat mewakili suara pekerja, Sarana Informasi bagi pekerja dan Memberikan layanan pada pekerja.

\section{Kepuasan Kerja}

Kepuasan kerja merupakan hal yang menarik dan penting karena kepuasan kerja yang dirasakan karyawan dapat mempengaruhi jalannya organisasi secara keseluruhan. Kepuasan kerja mempunyai pengaruh yang cukup besar terhadap produktivitas organisasi baik secara langsung maupun tidak langsung.

Kepuasan kerja ini akan didapat apabila ada kesesuaian antara harapan pekerja dan kenyataan yang di dapatkan di tempatnya bekerja. Setiap individu memiliki kepuasan yang berbedabeda sesuai dengan sistem nilai yang berlaku pada dirinya. Makin tinggi penilaian terhadap kegiatan dirasakan sesuai dengan keinginan individu, maka makin tinggi kepuasannya terhadap kegiatan tersebut. Dengan demikian, kepuasan merupakan evaluasi yang menggambarkan seseorang atas perasaan sikapnya senang atau tidak senang, puas atau tidak puas dalam bekerja (Veithzal Rivai, 2011:856).

Sedangkan Wether dan Davis (2002) dalam Dwi Penny Hasmarini, Ahyar Yuniawan (2008), menyatakan bahwa kepuasan kerja adalah kondisi kesukaan atau ketidaksukaan menurut pandangan karyawan terhadap pekerjaannya. Kepuasan kerja dapat dikatakan sebagai perasaan dan reaksi individu terhadap lingkungan pekerjaannya. Lebih lanjut dikemukakan bahwa kepuasan kerja merupakan penilaian, perasaan atau sikap seseorang atau karyawan terhadap pekerjaannya dan berhubungan dengan lingkungan kerjanya, jenis pekerjaan, kompensasi, hubungan antar teman kerja, hubungan sosial ditempat kerjanya. Sehingga dapat dikatakan bahwa kepuasan kerja adalah dipenuhinya beberapa keinginan dan kebutuhan melalui kegiatan kerja atau bekerja.

Indikator kepuasan kerja yang akan digunakan dalam penelitian ini menurut Malayu S.P Hasibuan (2008 : 94), adalah sebagai berikut : Menyenangi pekerjaan, mencintai pekerjaan, Moral kerja, Kedisiplinan dan Prestasi kerja.

Hubungan antara keadilan prosedural partisipatif dan dukungan serikat pekerja terhadap kepuasan karyawan itu erat kaitannya. Oleh karena itu dukungan serikat pekerja sangat diharapkan dan mampu untuk menjalankan peran sebaik-baiknya, maka pekerja akan merasa puas ketika peran keadilan prosedural partisipatif dan dukungan serikat pekerjanya juga dilaksanakan dengan baik. 


\section{Data dan Sampel}

Penelitian ini menggunakan metode deskriptif. Data yang digunakan dalam penelitian ini adalah data Primer dan sekunder. Data primer diperoleh dari jawaban kuisioner yang dibagikan kepada responden dan data sekunder diperoleh dari perusahaan yang diteliti. Populasinya adalah seluruh karyawan super market UD. Putra TS Majalengka yang berjumlah 330 orang. Kuisioner disebar dan yang memenuhi dan layak untuk dijadikan sampel 100 orang.

\section{Operasionalisasi Variabel}

Variabel Keadilan Prosedural Partisipatif diadopsi dari Asep Qustolani (2018), proses dan data penelitian ini diukur dengan menggunakan indikator: Konsisten, Perbaikan, Representativ atau keterwakilan, Gagasan atau ide, Kehadiran dalam rapat, Koordinasi. Skala yang digunakan adalah skala likert dengan melihat pernyataan-pernyataan dalam bentuk kuesioner yang ditunjukan kepada responden, dengan nilai terendah poin 1 dan nilai tertinggi dengan poin 5 .

Dukungan Serikat Pekerja diadopsi dari Budiarti (2011), proses dan data penelitian ini diukur dengan menggunakan indikator: Sebagai sarana bernegosiasi, dapat mewakili suara pekerja, Sarana Informasi bagi pekerja dan Memberikan layanan pada pekerja. Dalam pengukuran variabel, skala yang digunakan adalah skala likert dengan melihat pernyataan-pernyataan dalam bentuk kuesioner yang ditunjukan kepada responden, dengan nilai terendah poin 1 dan nilai tertinggi poin 5 .

Kepuasan Kerja diadopsi dari Malayu SP. Hasibuan (2008;202), proses dan data penelitian ini diukur dengan menggunakan indikator: Menyayangi pekerjaan, Mencintai pekerjaan, Moral kerja, Kedisiplinan, Prestasi kerja. Dalam pengukuran variabel, skala yang digunakan adalah skala likert dengan melihat pernyataan-pernyataan dalam bentuk kuesioner yang ditunjukan kepada responden, dengan nilai terendah poin 1 dan nilai tertinggi poin 5 .

\section{Analisis Data}

Pengujian dilakukan dengan melakukan pengujian instrumen terlebih dahulu sebelum pengujian data dan pengujian hipotesis. Pengujian instrument dengan dua macam berupa uji validitas dan uji reliabilitas. Jawaban responden melalui kuisioner menggunakan skala likert akan menghasilkan data ordinal, maka untuk dapat dianalisis secara statistik data tersebut harus dinaikkan menjadi data interval yaitu dengan menggunakan Methods of Successive Interval (MSI).
Selanjutnya, pengujian dengan melakukan uji asumsi klasik, yaitu uji normalitas, multikoliniaritas, heteroskedastisitas dan autokorelasi. Sedangkan teknis analisis yang digunakan untuk menguji hipotesis 1 dan 2 digunakan model persamaan regresi ganda (Sugiyono, 2008 : 275), sebagai berikut:

$$
\mathbf{Y}=\mathbf{a}+\boldsymbol{\beta 1 X 1}+\boldsymbol{\beta 2 X} 2+\mathbf{e}
$$

Keterangan :

$\begin{array}{ll}\mathrm{Y} & =\text { Kepuasan Kerja Karyawan } \\ \mathrm{A} & =\text { Konstanta } \\ \beta 1 \mathrm{~s} / \mathrm{d} \beta 2 & =\text { Koefisien regresi } \\ \mathrm{X} 1 & =\text { Keadilan Prosedural Partisipatif } \\ \mathrm{X} 2 & =\text { Dukungan Serikat Pekerja } \\ \mathrm{e} & =\text { Standar Error }\end{array}$

Pengolahan data akan dilakukan dengan program SPSS versi 13.0

\section{HASIL DAN PEMBAHASAN}

\section{Uji Validitas}

Uji validitas ini dilakukan kepada 17 pernyataan, yang terdiri dari 6 pernyataan untuk variabel keadilan prosedural partisipatif, 6 pernyataan untuk dukungan serikat pekerja dan 5 pernyataan untuk variabel kepuasan kerja . Kriteria yang digunakan untuk menilai validitas adalah $\mathrm{r}_{\text {hitung }}$ $>\quad r_{\text {tabel }}$ (Sugiyono, 2014). Perhitungannya menggunakan SPSS 21 dan hasil untuk masingmasing variabel sebagai berikut:

Hasil uji validitas terhadap semua variabel yang diteliti, menunjukan bahwa $r_{\text {hitung }}$ untuk semua pernyataan lebih besar dari $r_{\text {tabel }}$ pada taraf signifikan 5\% yakni sebesar 0,195. Sehingga dapat disimpulkan bahwa seluruh butir pernyataan tersebut valid.

\section{Uji Reliabilitas}

Hasil uji reliabilitas dari ketiga variabel diatas yaitu keadilan prosedural partisipatif, dukungan serikat pekerja dan kepuasan kerja karyawan pada masing-masing variabel memiliki nilai $r_{\text {hitung }}>r_{\text {tabel }}$, artinya semua pernyataan dalam ketiga variabel tersebut reliable.

\section{Uji Normalitas}

Uji normalitas data dalam penelitian ini dilakukan dengan uji kolmogrov-Smirnov, uji grafik histogram dan uji grafik P-Plot. Adapun hasil uji normalitas data dalam penelitian ini dapat dilihat pada tabel 1 berikut: 
Tabel 1.

Hasil Uji Normalitas Data

One-Sample Kolmogorov-Smirnov Test

\begin{tabular}{llr}
\hline & & $\begin{array}{c}\text { Unstandardized } \\
\text { Residual }\end{array}$ \\
\hline $\mathrm{N}$ & Mean & 100 \\
Normal Parameters ${ }^{\text {a,b }}$ & Std. Deviation &, 0000000 \\
& Absolute & 9,40499775 \\
Most Extreme Differences & Positive &, 073 \\
& Negative &, 073 \\
Kolmogorov-Smirnov Z &,- 055 \\
Asymp. Sig. (2-tailed) &, 726 \\
$\begin{array}{l}\text { a. Test distribution is Normal. } \\
\text { b. Calculated from data. }\end{array}$ &, 668 \\
\hline
\end{tabular}

Berdasarkan tabel 1 dapat diketahui bahwa nilai K-S sebesar 0,726 dengan taraf signifikan (Asymp. Sig 2-tailed) adalah 0,668 menunjukan signifikasi yang lebih besar dari $a=0,05$. Sehingga data dalam penelitian tersebut berdistribusi normal.

\section{Uji Multikolinearitas}

Pengujian untuk mendeteksi adanya problem multikolinearitas, maka dapat dilakukan dengan melihat nilai Tolerance dan Variance Inflation Factor (VIF) serta besaran korelasi antar variabel independen. Jika nilai tolerance lebih dari $0,10(10 \%)$ dan nilai VIF kurang dari 10 maka data tidak mengalami multikolinearitas.

Hasil analisis data dapat diketahui bahwa keadilan prosedural partisipatif dan dukungan serikat pekerja nilai VIF sebesar $1,060<10$ dan hasil perhitungan nilai tolerance sebesar 0,943 > 0,10 . Artinya bahwa tidak ada multikolinearitas antar variabel independen dalam model regresi maka variabel dapat digunakan dalam penelitian.

\section{Uji Heteroskedastisitas}

Hasil pada gambar grafik Scatterplot dapat dilihat bahwa titik-titik menyebar secara acak, serta tersebar baik di atas maupun dibawah angka nol pada sumbu Y. Hal ini berarti, tidak terjadi heteroskedastisitas pada model regresi, sehingga model regresi layak dipakai untuk memprediksi kepuasan kerja berdasarkan masukan variabel independen keadilan prosedural partisipatif dan dukungan serikat pekerja.

\section{Uji Autokolerasi}

Hasil analisis diketahui nilai d (DurbinWaston) $=2,158$. Untuk mengetahui nilai dU dan $\mathrm{dl}$ dapat dilihat pada kriteria pengujian Durbin Waston. Karena $\mathrm{n}=100$ dan $\mathrm{k}=2$ (jumlah variabel independen), maka nilai dl sebesar 1,6337 dan dU sebesar 1,7152 .
Persamaan yang sesuai dengan penelitian ini yaitu $\mathrm{dU}<\mathrm{dw}<(4-\mathrm{dU})$ dimana $1,6337<2,158<$ 2,2848 (4-1,7152). Artinya tidak terdapat autokorelasi baik itu positif maupun negatif.

\section{Analisis Regresi Berganda}

Berikut merupakan hasil analisis regresi berganda yaitu:

Tabel 2.

Hasil Uji Analisis Regresi Berganda Coefficients $^{\mathrm{a}}$

Unstandardized T Sig. Correlations

$\begin{array}{lll}\text { Coefficients } & \text { Zero- Part Par } \\ \text { Std. }\end{array}$

\begin{tabular}{|c|c|c|c|c|c|c|c|c|}
\hline \multirow{2}{*}{\multicolumn{2}{|c|}{ (Nivici }} & \multicolumn{2}{|c|}{ Coefficients } & \multirow[t]{2}{*}{ 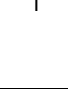 } & \multirow[t]{2}{*}{ sig. } & \multicolumn{3}{|c|}{ 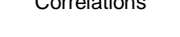 } \\
\hline & & B & $\begin{array}{l}\text { Std. } \\
\text { Error }\end{array}$ & & & $\begin{array}{l}\text { Zero- } \\
\text { order }\end{array}$ & $\begin{array}{c}\text { Part } \\
\text { ial }\end{array}$ & $\begin{array}{c}P a r \\
t\end{array}$ \\
\hline \multirow{4}{*}{1} & (Constant) & 29,208 & 6,144 & 4,754 & ,000 & & & \\
\hline & $\begin{array}{l}\text { Keadilan Prisedural } \\
\text { Partisipatif }\end{array}$ & 285 & 098 & 2,893 & ,005 & ,316 & 282 & $\begin{array}{l}27 \\
6\end{array}$ \\
\hline & Dukungan Serikat Pekerja & 131 & 098 & 2,334 & ,018 & 199 & ,134 & $\begin{array}{l}12 \\
7\end{array}$ \\
\hline & a. Dependent Variable: $\mathrm{K}$ & Juasan I & & & & & & \\
\hline
\end{tabular}

Sumber :Output SPSS Versi 21, 2018.

Berdasarkan tabel 2, maka didapat persamaan model regresi linear berganda sebagai berikut :

$$
Y=29,208+0,285_{X 1}+0,131_{X 2}
$$

\section{Uji Hipotesis}

\section{Hipotesis Pertama (Pengaruh Keadilan Prosedural Partisipatif Terhadap Kepuasan Kerja)}

Untuk variabel keadilan prosedural partisipatif diperoleh nilai $t_{\text {hitung }}$ sebesar 2,893 bertanda positif dengan signifikansi 0,005. Pada derajat bebas $(\mathrm{df})=\mathrm{n}-\mathrm{k}=100-2=98$ dengan $\alpha=$ 5\%. Pada tabel distribusi t untuk $\mathrm{dk}=98$ adalah 1,984, maka diperoleh $t_{\text {hitung }}$ sebesar 2,893 dan $t_{\text {tabel }}$ sebesar 1,984 dengan taraf signifikansi 0,005, karena nilai $t_{\text {hitung }} 2,893>t_{\text {tabel }} 1,984$ dan nilai signifikansinya $0,005<0,05$, maka Ho ditolak, sehingga hipotesis pertama yang menyatakan bahwa terdapat pengaruh secara signifikan antara keadilan prosedural partisipatif terhadap kepuasan dapat dibuktikan kebenarannya.

Hasil ini mendukung penelitian yang dilakukan Asep Qustolani (2015)

\section{Hipotesis Kedua (Pengaruh Dukungan Serikat Pekerja Terhadap Kepuasan Kerja)}

Untuk variabel dukungan serikat pekerja diperoleh nilai $t_{\text {hitung }}$ sebesar 2,334 bertanda positif dengan signifikansi 0,018 . Pada derajat bebas $(\mathrm{df})=$ $\mathrm{n}-\mathrm{k}=100-2=98$ dengan $\alpha=5 \%$. Pada tabel distribusi $\mathrm{t}$ untuk $\mathrm{dk}=98$ adalah 1,984, maka diperoleh $t_{\text {hitung }}$ sebesar 2,334 dan $t_{\text {tabel }}$ sebesar 1,984 dengan taraf signifikansi 0,018, karena nilai $t_{\text {hitung }} 2,334>t_{\text {tabel }} 1,984$ dan nilai signifikansinya $0,018<0,05$, maka Ho ditolak, sehingga hipotesis 
kedua yang menyatakan bahwa terdapat pengaruh secara signifikan antara keadilan prosedural partisipatif terhadap kepuasan dapat dibuktikan kebenarannya.

Hasil ini mendukung penelitian yang dilakukan Budiarti (2011) dan penelitian yang dilakukan Euis Rikawati (2015), yang menyatakan bahwa dukungan serikat pekerja berpengaruh positif terhadap kepuasan kerja, artinya semakin besar dukungan serikat pekerja, maka akan semakin tinggi tingkat kepuasan karyawannya.

\section{KESIMPULAN DAN SARAN}

\section{Kesimpulan}

Kesimpulan ini akan mengemukakan hasil dari pengujian hipotesis 1, bahwa: Keadilan Prosedural Partisipatif berpengaruh positif dan signifikan terhadap Kepuasan Kerja karyawan terbukti. Artinya, semakin baik Keadilan Prosedural Partisipatif yang dilaksanakan, maka semakin tinggi tingkat Kepuasan Kerja karyawan. Pengujian hipotesis 2, bahwa: Dukungan Serikat Pekerja berpengaruh positif dan signifikan terhadap Kepuasan Kerja karyawan, terbukti. Artinya, semakin baik dukungan serikat pekerja, maka akan semakin meningkat pula kepuasan kerja karyawannya.

Penelitian ini memiliki beberapa keterbatasan yang dapat mempengaruhi hasil penelitian ini, antara lain (1) Responden penelitian terbatas pada karyawan dalam satu perusahaan, (2) Data yang dianalisis ini hanya menggunakan instrument yang berdasarkan persepsi jawaban responden, (3) Pengukuran sikap dengan skala likert yang bernilai 1 sampai dengan 5 .

\section{Saran}

Hasil penelitian membuktikan seluruh hipotesis yang diajukan dapat diterima, hal ini memberikan peluang bagi penelitian selanjutnya untuk menggunakan objek penelitian yang lain atau yang lebih luas cakupannya serta mengembangkan dengan menambah variabel lain yang digunakan.

\section{DAFTAR PUSTAKA}

Dwi Penny Hasmarini, Ahyar Yuniawan. 2008. "Pengaruh Keadilan Prosedural dan Distributuf terhadap Kepuasan Kerja dan Komitmen Afektif". Universitas Diponegoro. Jurnal Bisnis Strategi Vol. 17 No. 1 Juli 2008.

Euis Rikawati. 2015. Pengaruh Keadilan Prosedual Partisipatif Dan Dukungan Serikat Pekerja Terhadap Kepuasan Kerja Karyawan Pada Perusahaan Daerah Air Minum Pusat
Kabupaten Majalengka. Skripsi (Tidak dipublikasi) FEB Universitas Majalengka.

Fitri Nugraheni, Ratna Yulia Wijayanti. 2009. "Pengaruh Keadilan Distributif dan Keadilan Prosedural Terhadap Kinerja”.

Hasibuan, Malayu S.P., (2008). Manajemen Smber Daya Manusia, Edisi Revisi Jakarta, Penerbit Bumi Aksara.

Hamong Santoso dan Indi Djastuti. 2011. "Partisipasi Pekerja dalam Serikat Pekerja”. Universitas Diponegoro. Jurnal Ekonomi Pembangunan Volume 12, Nomor 2, Desember 2011.

Imam Ghozali. 2011. Aplikasi Analisis Multivariate dengan Program SPSS. Edisi 5. Badan Penerbit Universitas Diponegoro, Semarang.

Indah Budiarti. 2011. Serikat Pekerja, Education Book Revised Edition. Nov. 2011.

Qustolani, Asep. Suharnomo, Lala Irviana and Imam Ghozali. 2018. The Modelling of Participative Procedural Juctice to Improve Employee Job Satisfaction Using Structural Equation Modeling ( Empirical Study on Textile Industry and Products in West Java). International Journal of Civil Engineering and Technology (IJCIET) Volume 9, issue 2, Februari 2018, pp. 883-897. Article ID: IJCIET_09_02_085

Qustolani, Asep. 2015. "Pemodelan Keadilan Prosedural Partisipatif dalam usaha Meningkatkan Kinerja Karyawan (Studi empiris pada industry tekstil dan produk tekstil di Jawa Barat). Disertasi ( Tidak dipublikasi). PDIE. Universitas Diponegoro Semarang.

Rivai, Veithzal. 2011. Manajemen Sumber Daya Manusia Untuk Petusahaan Dari Teosi ke Praktik. Jakarta : Raja Grafindo Persada.

Sugiyono. 2014. Statistika untuk Penelitian . Bandung : Alfabeta.

Tsui. 1997. Alternative Approaches to the Employee Organization Relationship Does Investment in Employees Pay Off. Acad Manag J. 1997; 40 (5):1085-121. 